\title{
ANALYSIS ON POLYTECHNIC OF TONGGAK EQUATOR STUDENTS' ERROR IN WRITING
}

\author{
Magpika Handayani \\ Polytechnic of Tonggak Equator Pontianak \\ Magpikahandayani@yahoo.com
}

\begin{abstract}
Students are required to express something in the form of written expression because it is one of skill in learning language. Students are required to be good in grammar to regulate every word with a good structure. However, there are error made by students that are caused by some grammatical factors such as punctuation, word selection, tenses, spelling, use of article and capitalization. This research is qualitative research, and the writer describes the error made by students by looking at the factors commonly cause the error. The results showed that student error in writing lies in misused form, words form, words choice, verb tense, misplace words, spelling, punctuation, capitalization, and article. The occurrence of an error in writing is due to first language interference, style of translation, and carefulness in writing. The dominant error made by the student lies in the use of the word form in the sentence.
\end{abstract}

Keywords: analysis, writing error, grammatical errors.

\begin{abstract}
Abstrak
Siswa dituntut untuk mengekspresikan sesuatu dalam bentuk ekspresi tertulis karena merupakan salah satu keterampilan dalam belajar bahasa. Siswa dituntut menguasai tata bahasa untuk mengatur setiap kata dengan struktur yang baik. Namun, ada kesalahan yang dilakukan oleh siswa yang disebabkan oleh beberapa faktor tata bahasa seperti tanda baca, pemilihan kata, tenses, ejaan, penggunaan artikel dan penggunaan huruf besar. Penelitian ini adalah penelitian kualitatif, dan penulis menggambarkan kesalahan yang dilakukan oleh siswa dengan melihat faktor-faktor yang menyebabkan kesalahan tersebut. Hasil penelitian menunjukkan bahwa kesalahan siswa dalam menulis terletak pada bentuk yang disalahgunakan, bentuk kata-kata, pilihan kata-kata, kata kerja, kata-kata salah tempat, ejaan, tanda baca, huruf kapital, dan artikel. Terjadinya kesalahan dalam menulis adalah karena gangguan bahasa pertama, gaya terjemahan, dan kehati-hatian dalam menulis. Kesalahan dominan yang dilakukan oleh siswa terletak pada penggunaan bentuk kata dalam kalimat.
\end{abstract}

Kata kunci: analisis, kesalahan penulisan, kesalahan tata bahasa. 


\section{BACKGROUND}

Writing is one of the skills taught in college. Students should be able to express the habits and activities in the form of written expression. However, writing requires a lot of preparation and ideas, moreover; students require good grammar to regulate every word in good order so it would be good writing. Students who have good writing skills will find it easier to write in English in any situation. Writing is a written communication tool among people in the world for several reasons. Writing skills involve language production that is considered to be productive skills. Writing contributed to express ideas through written expression for all students.

As a productive skill, writing is not like speech or other receptive skills. Writing is one of the most difficult skills because it requires not only a lot of vocabulary in composing paragraphs, but also correct grammar in order to understand to other writing rules. Therefore, writing paragraphs takes a lot of time. Writing is often not tied to time in the way of conversing. When writing, most students often have more time to think than do oral activity. They can go through what they know in their mind, and even consult with a dictionary, grammar book or other reference material to help them.

In order to specify the problem in this research, the writer would like to state two following problem. The problems in this research are:

1. What is the grammatical error made by polytechnic of Tonggak Equator students in writing?

2. What is the most dominant grammatical error made by polytechnic of Tonggak Equator students in writing?

Through this study, the writer is interested to know grammar errors might be the most widely performed by students in writing. The problem raised in this research is to find general error in grammatical in writing, to know the cause of error done by students of Polteq Pontianak, and to know the dominant mistake made by student in writing. According to Al- Shujairi (2017) there are some c 
ategories in grammar influencing the error in writing, the categories are as follow:

\section{Grammar in Writing}

According to Knapp \& Watkins (2005:38) Grammar plays important role in writing. Grammar may give contribution in the meaning of text we write. The use of good grammar in writing may help reader to understand the purpose of the writer in delivering process. The use of grammar in writing by non native speaker like students in school may happen since the first language interference influence strongly in the process of writing. The grammatical errors made by non-native speakers may be influenced by their first language, and are hardly random. Understanding the nature of these errors, and the contexts in which they occur, can be helpful to grammar checking systems. However, to our knowledge, there has not been any reported effort to build non-native language models automatically from our own understanding. Basically grammar consists of subject and predicate which will form a sentence no matter how long the sentence is, it is easy to break it into subject and predicate.

The students understanding about the correct changing form of verb tense they write in their writing and their confusedness to put to be in the non-verbal or verbal sentence they write may be another factor which causes some error may occur. It could be caused by the interference of the students' first language or their deficiency competence that reflected on how much the students had learnt the grammatical rules of the target language.

Grammatical error compares between the errors a learner makes in producing the target language and the target language form itself. Ggrammatical error provides a broader range of possible explanations than contrastive analysis for researchers/teachers to use to account for errors, as the latter only attributed errors to the Native Language. It means that grammatical error which concerns in learners' error can explain more about learner's error.

The following is the example of error that is made by the students when the teacher gave them a writing exercise: 
Table 2.1

Students Error in Writing

\begin{tabular}{lll}
\hline \multicolumn{1}{c}{ Part of grammar } & \multicolumn{1}{c}{ Error in Grammar } & \multicolumn{1}{c}{ The correct sentence } \\
\hline Verb tense & I am go to the beach & I went to the beach \\
\hline Spelling error & I will go to the beat & I will go to the beach \\
\hline Punctuation & Do you know this place! & Do you know this place? \\
\hline Capitalization & i am so happy & I am so happy \\
\hline Article & I like a apple & I like an apple \\
\hline
\end{tabular}

\section{Verb Tense Error}

The error happens to the students' writing and they are considered as error in writing. The first error is "verb tense", the students are not able to differentiate the use of be (is, am, are) in the verbal sentence or nominal sentence. When a sentence contains a subject-verb agreement error, most often the problem is that the verb in the sentence is agreeing with a word that is not the actual subject. Usually it is agreeing with a noun that is closer to the verb than the actual subject. This kind of error is also called the "nearest-noun" agreement error. Verb tense agreement error occurs frequently on students' writing due to their first language which may interfere on their foreign language, Kamlasi \& Nokas, 2017).

\section{The spelling Error}

The next error is the spelling, the students spell the word "beach" with the other word because probably "beat" is more familiar for them. Spelling may occur on students' writing because they may be hurry in writing the sentence. Al- Jarf cited in Miressa \& Dumessa (2011:3) state that spelling errors can be either freely produced or elicited by certain tasks. Any word that does not match the target word in part or in full is marked as a misspelling. Any faulty word, faulty grapheme (single vowel, single consonant, vowel digraphs, consonants digraphs, phonogram, suffix, or prefix) within a word is counted as error. Spelling errors, specifically homophone or near-homophone errors (such as confusing, similar sounding words like affect, effect and too, two), are problematic for both native and non-native speakers.

\section{Punctuation Error}


The next errors which may occur to students' writing is punctuation, the students use wrong punctuation for different use of sentence. The punctuation may help a writer to develop their writing by giving a signal in order to give good information to the reader. The most common use of a colon is to introduce a list. A frequent mistake is to use a colon to introduce a list that is actually a required part of the sentence. In this case, the colon is incorrect. The use of punctuation may help the writer to develop their writing but on the other hand it may also be confusing if it is put in the wrong way. The wrong positioning of the punctuation possibly occurs on students' writing due to their poor knowledge in punctuation. Moreover; take care with the punctuation of proper nouns, because they are the special individual names of people, towns, countries, newspapers, days of the week, businesses, and so on, they require initial capital letters

\section{Capitalization Error}

Capitalization also becomes the problem in students writing, they put " $\mathrm{i}$ " not in capital because they do not realize the function between "I" and " $i$ ". Beason \& Lester states that some words (proper nouns and proper adjectives) should be capitalized to show they are the official names or nicknames of specific persons, places, things, or events. In addition, many words are capitalized because they are derived from official names. For example, the word "English" must be capitalized because it is derived from the name of a country (England). Also, "South" should be capitalized since people widely recognize it as the name of a specific region. Moreover; capitalization is not an issue in speech, so the rules can be difficult to learn. Compounding the problem is the fact that capitalization varies according to how words are used in a sentence (for example compare My uncle is here with I saw Uncle Brett there). The writer must be careful because errors in capitalization can confuse readers by sending the wrong message about whether a word is the specific name of somebody (or something) or whether the word is merely a general description. 


\section{Article Error}

Article is another error made by students especially in determining the object. Article "a" is different from article "an" they probably do not realize the use of "a" in front of consonant and "an" in front of Vowel. The correct use of article will influence the meaning of the word that is written on the sentence. The wrong use of article "a" and "the" will give different interpretation by the reader to understand the writing; therefore, it is necessary to put the article in front of the words which need an article.

The definite article is always the, which is used with all types of common nouns (singular and plural, count and no count). Using indefinite articles is more complicated. The indefinite articles "a" and "an" are used only with singular count nouns (a truck, an apple). Some is used with plural count nouns (some trucks, some apples) and all no count nouns (some violence, some water).

English language has a more complex tense system than many languages do, and it can be difficult for non-native and even native speakers to master. Several common errors in English grammar stem from the way that English conjugates verb tense, the way it changes verbs to communicate past, present and future action. The example above supports the example that is shown on the table. The verb tense error in English tense is due to the difference of structure from the source language of the learners. The strength of the first language results in error on the students' sentence especially in writing.

\section{Errors and Mistakes}

It is essential here to make a distinction between mistakes and errors. In order to analyze learners' language in an appropriate perspective, it is crucial to make a distinction between mistakes and errors, technically two very different phenomena. A mistake refers to a performance error that is either a random guess or a "slip," in that it is a failure to utilize a known system correctly. Two things need to be stated here: Firstly, mistakes do not require special treatment assuming they are recognized. Secondly, error here refers to structures only. A mistake can 
be self-corrected, but an error cannot. Errors are "systematic," i.e. likely to happen regularly and not recognized by the learner. Hence, only the teacher or researcher would locate them, the learner would not. Mistakes must be carefully distinguished from errors of a second language learner, idiosyncrasies in the language of the learner that are direct manifestations of a system within which a learner is operating at the time. An error, a noticeable deviation from the adult grammar of a native speaker, reflects the competence of the learner, (Singh, Razak \& Ravinthar, 2017:18).

Error is a situation when a speaker unsuccessfully expresses the language well in the target language. The unsuccessfully use of language brings about strangeness in the use of language, James, 2013:1). Error in language may occur because of 4 reasons and in this case the writer would like to express it into 4 categories, they are: grammatically, acceptability, correctness, and strangeness or infelicity. From 4 categories propose in this writing, it is obviously that grammatical and correctness is going to be investigated in this writing.

Grammatically error is when the speaker does not use the form of the language well. Grammatical error is the aspect that is mostly found in writing because the writer does not express his or her language by sound. Acceptability means when someone utters the language, the knower of language will decide whether the language is acceptable or not. Correctness is the situation when the speaker can understand and use the grammar based on the language pattern they learn prescriptively. Correctness is the category that is commonly known as mistake. Strangeness or infelicity is the abnormal form of language that is applied by someone in the target language they use.

\section{Types of Error}

There are some types of error which should be understood by the writer in order to analyze the error of the students in writing. The following are the types of error which is commonly identified in the students' writing. The error which is going to be discussed in this writing is the error dealing with the students' writing. 
Jurnal Pendidikan Bahasa, Vol. 7, No. 2, Desember 2018

The types of errors which frequently occur on students' writing are discussed as follow: 


\section{Global and Local Error}

There is local and global errors. Local errors do not hinder communication and understanding the meaning of an utterance. Global errors, on the other hand, are more serious than local errors because global errors interfere with communication and disrupt the meaning of utterances. Local errors involve noun and verb inflections, and the use of articles, prepositions, and auxiliaries. Global errors, for example, involve wrong word order in a sentence. Global errors hinder communication; they prevent the hearer from comprehending some aspect of the message. For example, "Well, it's a great hurry around," in whatever context, may be difficult to interpret. Local errors do not prevent the message from being heard, usually because there is only a minor violation of one segment of a sentence, allowing the hearer/reader to make an accurate guess about the intended meaning. "A scissors," for example, is a local error.

\section{Performance Error and Competence Error}

According to Touchie (1986:76) researchers in the field of applied linguistics usually distinguish between two types of errors: performance errors and competence errors. Performance errors are those errors made by learners when they are tired or hurried. Normally, this type of error is not serious and can be overcome with little effort by the learner. Competence errors, on the other hand, are more serious than performance errors since competence errors reflect inadequate learning. In this connection, it is important to note that to distinguish between mistakes which are lapses in performance and errors which reflect inadequate competence

\section{The Understanding of Writing}

Writing is one of skill in English and one of the most essential skill in learning English. Writing is productive skill because it produces ideas through written text. In the writing process, people will deliver their idea in the form written text and there is a purpose that should be delivered to the other people. 
The purpose of writing should be understood in order to create an interaction among the people so that there is a respond that is made.

Writing is the process of delivering ideas in the form of written text. The essence of writing lies in the purpose of writing itself. The purpose of writing is the reason why someone doing the writing. In writing, someone needs to consider the paragraph and essay because they have their own structure. A paragraph has three necessary parts: the topic sentence, the body, and the concluding sentence. The topic sentence states the main point. The topic sentence is often the first sentence of the paragraph. The body supports (shows, explains, or proves) the main point with support sentences that contain facts and details. The concluding sentence reminds readers of the main point and often makes an observation.

An essay is a piece of writing that examines a topic in more depth than a paragraph. A short essay may have four or five paragraphs, totaling three hundred to six hundred words. A long essay is six paragraphs or more, depending on what the essay needs to accomplish — persuading someone to do something, using research to make a point, or explaining a complex concept. An essay has three necessary parts: the introduction, the body, and the conclusion. The introduction states the main point, or thesis, generally in a single, strong statement. The introduction may be a single paragraph or multiple paragraphs. The body supports (shows, explains, or proves) the main point. It generally has at least three support paragraphs, each containing facts and details that develop the main point. Each support paragraph has a topic sentence that supports the thesis statement. The conclusion reminds readers of the main point. It may summarize and reinforce the support, or it may make an observation based on that support. Whether it is a single paragraph or more, the conclusion should relate back to the main point of the essay.

It is important to make sure that the uses of writing cover the range of uses that learners will perform in their daily lives. These can include filling forms, making lists, writing friendly letters and business letters, note-taking and 
academic writing. Each of these types of writing involves special ways of organizing and presenting the writing and this presentation also deserves attention.

Writing is a process that is made in order to reach a goal through written expression. One way of focusing attention on different aspects of writing is to look at writing as a process. One possible division of the writing process contains the following seven sub processes. Considering the goals of the writer, having a model of the reader, gathering ideas, organizing ideas, turning ideas into written text, reviewing. Those steps may become a guideline for the writer to improve their writing capability.

The students must be encouraged in order to write and reach their goal in writing. An important way of encouraging writers to keep their goals and audience in mind is to provide them with feedback about the effectiveness of their writing. This feedback can be direct comment on the writing as a piece of writing or it can be a response to the message. Teachers should also check their writing program to make sure that learners are given practice in writing for a range of purposes to a range of readers. Techniques for gathering ideas about a topic can be classified into three groups. The first group consists of open-ended, free-ranging activities where all ideas are considered or the learners follow whatever path their mind takes. Typical of these are brainstorming and quick writing. These activities could be preceded by relaxation activities where learners are encouraged to use all their senses to explore a topic. The second group consists of systematic searching procedures such as questioning (who, why, where, when ....) or filling in an information transfer diagram. In all cases the learners have set steps to follow to make sure they consider all the important parts of the topic.

Research by Franken cited in Nation (2009:117) has shown that when learners are in command of the ideas in a topic, the grammatical errors are significantly reduced in their writing. The third group in his research consists of techniques which help learners gather and organize ideas at the same time. These include using tree diagrams and concept diagrams or maps. These all involve arranging ideas into relationships, particularly according to importance and level 402 
of generality. One of the biggest blocks in writing is a lack of ideas. Techniques which help learners gather ideas will have good effects on all other aspects of their writing. For group brainstorming the learners get together in small groups and suggest as many ideas about the writing topic that they can think of. At first no idea is rejected or criticized because it may lead to other ideas. One person in the group keeps a record of the ideas. List making is also one of the way that can be used by students to write. With list making before writing, each learner makes a list of ideas to include in the writing. After the list is made then the learner attempts to organize it and this may lead to additions to the list. Looping is when each learner writes as quickly as possible on the topic for 4 or 5 minutes. Then they stop, read what they have written, think about it and write one sentence summarizing it.

The way learners organize ideas gives them a chance to put their own point of view and their own thought into their writing, particularly in writing assignments and answering examination questions. Often the ideas to be included in an assignment do not differ greatly from one writer to another, but the way the ideas are organized can add uniqueness to the piece of writing. Two possible ways of approaching the organization of academic writing is to rank the ideas according to a useful criterion or to classify the ideas into groups. The use of sub-headings in academic writing is a useful check on organization.

Some learners are able to say what they want to write but have difficulty in putting it into written form. That is, they have problems in translating their ideas into text. Some learners can do this but are very slow. They lack fluency in turning ideas to text. A possible cause is the difference between the writing systems of the learners' first language and the second language. The learners of English who have different script have greater difficulty in this part of the writing process than Indonesian or French learners do because of the different written script. If the learners' first language uses a different writing system from English, then there is value in practicing the formal skills of forming letters of the alphabet and linking these letters together. There is also value in giving some attention to 403 
spelling. Some learners will find problems even in saying what they want to write. One cause may be lack practice in writing in any language. Each cause requires different techniques to deal with it and teachers need to consider how to discover the causes and how to deal with them, (Nation, 2009:119). The well - organized of writing may help the students to develop their writing with a good procedure.

\section{METHOD}

Error Analysis is considered as qualitative research. A qualitative research can be conducted through descriptive. In this study, the writer describes the finding of his observation and employs descriptive to deliver the result of research. According to Borg and Gall (2007:446), descriptive represents a basic form of qualitative research. The writer classified the error made by students. The number of error will be referred to the common error clarification such as, misused form ( singular-plural), Words form, word choice, verb tense, misplace words (word order), spelling, Punctuation, Capitalization, Article, and Meaning of the sentence.

\section{Population}

The population in this research is polytechnic of Tonggak Equator Students especially semester. The numbers of students are 210 students.

\section{Sample}

In order to ease the process of collecting data, not all students in semester

\section{Data Collecting}

The writer collected data by giving a writing instruction to students. The instrument is a text sheet. The writer asked students to write their unforgettable moments. When the students complete their paper, the teacher collect and circle the wrong words or phrase. Then, the writer asked the students to fix and revise the circle words and collect the papers again. After all the papers are collected, the writer analyzed the students' writing to find the grammar error.

\section{Data Analysis}


The writer used qualitative research in this study which is conveyed in descriptive analysis way to describe and to interpret the result of qualitative data. To get the qualitative result, the data in the form of students writing was analyzed and the writer drw up the conclusion based on the performance of students writing. The errors were checked one by one and the writer made the number of error in each error classification in the students writing. The writer collects the result of students' writing in order to analyze the result and classify the result in the form of common error, cause of error and the dominant error made by student.

\section{DISCUSSION}

The errors done by the students cover the grammar categories of the research as follows, misused form, words form, words choice, verb tense, misplace words, spelling, punctuation, capitalization, article, and meaning. To find writing errors by students of Polteq Pontianak, the writer instructs students to write an article related to their unforgettable moment. Students were expected to write about their last holiday because the writer wanted to know the error made in their writings. Based on these data, the writer briefly described the errors made by the students.

\section{Dominant Error in Writing}

The writer also investigated the dominant error committed by the Supreme students so that a way out can be found and will be very helpful for faculty and great students to solve their problems in writing, especially in the writing of the text for a recount. In writing recount text, simple past tense is used to express the past activity. The following is an explanation of the dominant error committed by students in writing.

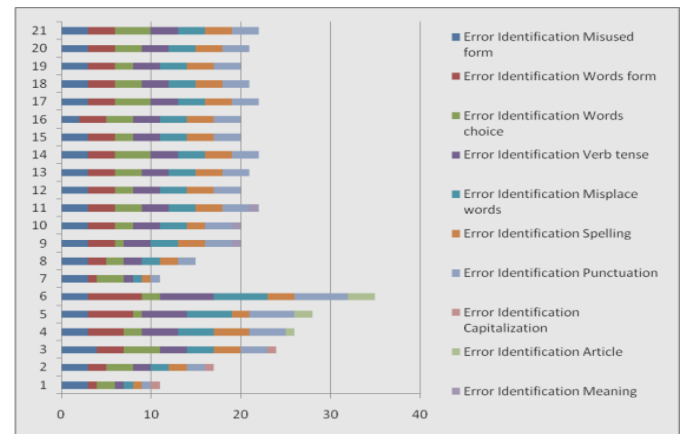


The dominant error made by the student lies in the use of the word form in the sentence structure. Dominance in the table can be seen from the blue line which nearly all students did the same thing with the same intensity. On the other hand, the other lines show the difference in the intensity of making mistakes in the writing of the recount. Overall, the students have an equation that is the error of using sentence structure especially in subject- verb agreement.

\section{CONCLUSION}

Common error made by the student of Polteq are abuse of form, the form of words, spelling, punctuation, capitalization, articles, and giving wrong word translation which result in wrong use of word in sentences they create. Errors are often made by students in their writing. All students make the same mistakes in their sentence especially in using the simple past tense. The errors are caused by their understanding of sentence patterns and their first language interference. The dominant error made by the student lies in the use of the word form in the sentence structure. Students have difficulties in distinguishing the form of past tense and present.

\section{BIBLIOGRAPHY}

Al-Shujairi, Yasir Bdaiwi. 2017. Grammar errors in the writing of Iraqi English Language Learner. International journal of Education and literacy studies.DOI: 10.7575/aiac.ijels.v.5n.4p.122

Beason, Larry \& Lester, Mark. 2012. A Commonsense Guide to Grammar and Usage. Six Edition. Bedford. New York.

Borg, Walter R, Gall, Joyce P \& Gall, Meredith D. (2007). Educational Research. Eight Edition. Boston. Pearson. 
Kamlasi, Imanuel \& Nokas, Darni Nopi.2017. Grammatial error in writing of the second class students of SMA Kristen Soe. METATHESIS, Vol. 1, No. 1, April 2107.

Knapp, Peter \& Watkins, Megan. 2005. Genre, Text, Grammar. New South Wales Press. Australia

Miressa, Mihiretu \& Dumessa, Melkamu.2011. Investigating factors contributing to grade nine students' spelling errors at Don Bosco High and Preparatory School in Batu. Journal of Language and Culture Vol. 2(6). pp. 103-115, June 2011 Available online http://www.academicjournals.org/JLC

Nation,I.S.P. 2009. Teaching EFL/ ESL Reading and writing.ESL \& applied linguistic professional series

Singh, Charanjit khaur swaran, Razak Nur Qistina Abd, Ravinthat, Thilaga. 2017. Grammar error made by ESL Tertiary Students in writing. English Language Teaching; Vol. 10, No. 5; 2017

Touchie, Hanna Y. 1986. Second Language Learning Errors Their Types, Causes, And Treatment. JALT Journal, Volume 8, No. I 